\title{
Ent-11 $\alpha$-hydroxy-15-oxo-kaur-16-en-19-oic-acid induces apoptosis and cell cycle arrest in CNE-2Z nasopharyngeal carcinoma cells
}

\author{
KEFENG WU ${ }^{1 *}$, YI LIU $^{1,2^{*}}$, YINGNIAN LV ${ }^{1}$, LIAO CUI $^{1}$, WENDE LI $^{1}$, \\ JIANFA CHEN $^{3}$, NIAN CI LIANG ${ }^{4}$ and LI LI ${ }^{1}$
}

\begin{abstract}
${ }^{1}$ Guangdong Key Laboratory for Research and Development of Natural Drugs, Guangdong Medical College, Zhanjiang, Guangdong 524023; ${ }^{2}$ Department of Surgery, Prince of Wales Hospital, The Chinese University of Hong Kong, New Territories, Hong Kong, SAR; ${ }^{3}$ Department of General Surgery, 422 Hospital of PLA, Zhanjiang, Guangdong 524009;

${ }^{4}$ Institute of Biochemistry and Molecular Biology, Guangdong Medical College, Zhanjiang, Guangdong 524023, P.R. China
\end{abstract}

Received January 10, 2013; Accepted March 5, 2013

DOI: 10.3892/or.2013.2375

\begin{abstract}
Ent-11 $\alpha$-hydroxy-15-oxo-kaur-16-en-19-oic-acid (5F), a compound isolated from Pteris semipinnata L. (PsL), inhibits cell proliferation and induces cell apoptosis in several cancer lines. We found that $5 \mathrm{~F}$ induced apoptosis and $\mathrm{G} 2$ phase cell cycle arrest in the CNE-2Z nasopharyngeal carcinoma (NPC) cells, accompanied by a decrease of NF- $\kappa \mathrm{B}$ expression. $5 \mathrm{~F}$ suppressed the viability of CNE-2Z cells in a time- and dose-dependent manner. $5 \mathrm{~F}$ induced $\mathrm{G} 2 / \mathrm{M}$ phase cell cycle arrest, but did not induce p21. Further analysis revealed that CNE-2Z cells harbored two p53 mutations. 5F treatment resulted in mitochondrial apoptosis, associated with increased Bax/Bcl-2 ratio, upregulation of cytochrome $c$ in the cytosol, decreased NF- $\kappa \mathrm{B}-\mathrm{p} 65$ and increased $\mathrm{I} \kappa \mathrm{B}$. Of note, $5 \mathrm{~F}$ significantly sensitized CNE-2Z cells to cisplatin. $5 \mathrm{~F}$ did not increase ROS, but reduced ROS production alone or in combination with cisplatin. Our data suggest that $5 \mathrm{~F}$ is a potential anti-NPC drug for the development of single agent therapy and therapy in combination with cisplatin.
\end{abstract}

\section{Introduction}

The incidence rate of nasopharyngeal carcinoma (NPC) in men is higher in rural than in urban China. NPC is the seventh most common cancer in men in rural areas with an incidence

Correspondence to: $\mathrm{Dr} \mathrm{Li} \mathrm{Li}$, Guangdong Key Laboratory for Research and Development of Natural Drugs, Guangdong Medical College, Zhanjiang, Guangdong 524023, P.R. China

E-mail: 1i518@yahoo.cn

Professor Nian $\mathrm{Ci}$ Liang, Institute of Biochemistry and Molecular Biology, Guangdong Medical College, Zhanjiang, Guangdong 524023, P.R. China

E-mail: ncliang@gdmc.edu.cn

*Contributed equally

Key words: ent-11 $\alpha$-hydroxy-15-oxo-kaur-16-en-19-oic-acid, nasopharyngeal carcinoma, $\mathrm{p} 53, \mathrm{NF}-\kappa \mathrm{B}$, cisplatin rate of 6.08/100,000, followed by bladder cancer, brain cancer and lymphoma (1). Despite significant advances in the therapy and early diagnosis, the prognosis of patients with stage III and IV NPC remains poor, usually due to a relatively high incidence of locoregional recurrence or metastasis (2). Thus, there is an urgent need to develop effective and safe therapeutics for this malignancy.

Ent-11 $\alpha$-hydroxy-15-oxo-kaur-16-en-19-oic-acid (5F) is an active compound in Pteris semipinnata $\mathrm{L}$ (PsL). In vitro, $5 \mathrm{~F}$ has been shown to kill various human cancer cells including lung cancer cells, laryngeal cancer cells, thyroid carcinoma cells, gastric cancer cells and colorectal cancer cells via apoptotic pathways (3-7). Since 5F can induce apoptosis in cells of various types of cancer, it may also be a potential apoptosis-inducing drug in NPC therapy. In the present study, we examined the potential antitumor action of $5 \mathrm{~F}$ in a human NPC cell line, CNE-2Z, and explored the possible synergism between $5 \mathrm{~F}$ and cisplatin.

\section{Materials and methods}

Cell culture. CNE-2Z is a poorly differentiated human NPC cell line (8). CNE-2Z cells were cultured in RPMI-1640 medium (Sigma-Aldrich) containing $10 \%$ fetal bovine serum (FBS) (Sigma-Aldrich), $100 \mathrm{U} / \mathrm{ml}$ penicillin and $100 \mu \mathrm{g} / \mathrm{ml}$ streptomycin. Cells were cultured at $37^{\circ} \mathrm{C}$ in a humidified $5 \%$ $\mathrm{CO}_{2}$ incubator.

Mutational analysis of p53. Genomic DNA was extracted from CNE-2Z using a genomic DNA isolation kit (Sangon, Shanghai, China) following the manufacturer's instructions, and quantified using a NanoDrop spectrophotometer (NanoDrop Technologies, Wilmington, DE, USA). The primers for PCR are listed in Table I. A $300 \mathrm{ng}$ aliquot of genomic DNA was added to a PCR master mixture containing 1X PCR buffer (100 mM Tris-HCl, $500 \mathrm{mM} \mathrm{KCl,} \mathrm{pH} \mathrm{8.3),}$ $200 \mu \mathrm{M}$ each of deoxynucleoside triphosphate, $200 \mathrm{nM}$ primer, $1.5 \mathrm{mM} \mathrm{MgCl}$, and 2.5 units of Taq polymerase. PCR was performed under the following cycling conditions: $4 \mathrm{~min}$ at $95^{\circ} \mathrm{C}$, followed by $45 \mathrm{sec}$ at $94^{\circ} \mathrm{C}, 45 \mathrm{sec}$ at $68^{\circ} \mathrm{C}, 1 \mathrm{~min}$ at $72^{\circ} \mathrm{C}$ for 35 cycles and final extension for $8 \mathrm{~min}$ at $72^{\circ} \mathrm{C}$. The 
PCR amplicons were purified with Gel/PCR DNA Fragments Extraction kit (Sangon) and sequenced with the BigDye Terminator kit (Applied Biosystems, Foster City, CA, USA) and ABI Prism 3730 DNA Analyzer (Applied Biosystems) according to the manufacturer's instructions.

Ent-11a-hydroxy-15-oxo-kaur-16-en-19-oic-acid(5F). 5F was isolated from PsL as previously described (9) (Fig. 1A). 5F was dissolved in propylene glycol (PG) and diluted with the culture medium immediately prior to use (final PG concentration $\leq 1.2 \%$ ). In all experiments, the cells in RPMI-1640 medium plus PG only were used as the control.

Cell viability assay. CNE-2Z cells $\left(5 \times 10^{3}\right)$ were seeded in each well of a 96-well plate in $200 \mu \mathrm{l}$ medium. At $24 \mathrm{~h}$, the cells were exposed to $5 \mathrm{~F}(0-80 \mu \mathrm{g} / \mathrm{ml})$, cisplatin $(10 \mu \mathrm{g} / \mathrm{ml})$, or a combination of $5 \mathrm{~F}(10 \mu \mathrm{g} / \mathrm{ml})$ and cisplatin $(10 \mu \mathrm{g} / \mathrm{ml})$. Cell viability was examined after an additional 24,48 or $72 \mathrm{~h}$ using MTT assay. Drug effect was expressed as percentage relative to the controls. Morphology of the cells was examined $24 \mathrm{~h}$ after $5 \mathrm{~F}$ exposure under an inverted phase contrast microscope.

DAPI staining assay. Cells were fixed with $4 \%$ paraformaldehyde for $20 \mathrm{~min}$, washed with PBS, and then incubated with DAPI (2 $\mu \mathrm{g} / \mathrm{ml})$ (Beyotime Institute Biotechnology, Haimen, China) at room temperature (RT) for $10 \mathrm{~min}$. Following removal of free DAPI with PBS, cells were observed under a fluorescence microscope.

Cell cycle distribution. CNE-2Z cells were seeded at a density of $1 \times 10^{5}$ cells/well in a 6 -well plate. Following treatment, cells were fixed overnight with $70 \%$ ethanol at $-20^{\circ} \mathrm{C}$ and stained with PI solution $(100 \mu \mathrm{g} / \mathrm{ml})$ (Sigma-Aldrich). Cell cycle distribution analysis was performed using a flow cytometer.

Measurement of apoptosis. Following treatment, cells were harvested, washed with PBS and resuspended in 195- $\mu 1$ binding buffer. The samples were then incubated with $5 \mu 1$ Annexin V-FITC for $15 \mathrm{~min}$ in the dark at $4^{\circ} \mathrm{C}$ and subjected to flow cytometry analysis immediately. Data acquisition and analysis were performed on a Becton-Dickinson FACSCalibur flow cytometer using CellQuest software. Caspase-3 activity was measured using Caspase-3 Colorimetric Assay kit (Nanjing KeyGen Biotech. Co., Ltd., Nanjing, China) according to the manufacturer's instructions. Caspase-3 activity was expressed as: $\mathrm{OD}_{\text {test compound }} / \mathrm{OD}_{\text {control }}$.

Reactive oxygen species (ROS) generation. The intracellular ROS level was measured using a fluorescent dye DCFH-DA (ROS Assay kit, Beyotime Institute Biotechnology). Cells were exposed to $5 \mathrm{~F}(0$ and $10 \mu \mathrm{g} / \mathrm{ml})$, cisplatin $(10 \mu \mathrm{g} / \mathrm{ml})$, or a combination of $5 \mathrm{~F}(10 \mu \mathrm{g} / \mathrm{ml})$ and cisplatin $(10 \mu \mathrm{g} / \mathrm{ml})$ for $3 \mathrm{~h}$, and incubated in the dark with $10 \mu \mathrm{M}$ DCFH-DA in serum-free medium for $20 \mathrm{~min}$ at $37^{\circ} \mathrm{C}$. ROS generation was detected using a FACScan flow cytometer with the excitation and emission settings at 488 and $530 \mathrm{~nm}$, respectively.

Western blot analysis. Cells were lysed on ice in SDS Lysis Buffer (Beyotime Institute Biotechnology) supplemented with protease inhibitors and phosphatase inhibitor (Roche),
Table I. Primer sequences used to amplify p53 tumor suppressor gene.

\begin{tabular}{|c|c|c|}
\hline Exons & $\begin{array}{l}\text { Primer sequences } \\
\qquad\left(5^{\prime}-3^{\prime}\right)\end{array}$ & $\begin{array}{l}\text { Product } \\
\text { size (bp) }\end{array}$ \\
\hline $2-4$ & $\begin{array}{l}\text { F: GAAGTCTTGGGGATTTAGTGGT } \\
\text { R: CAAAAGCCAAGGAATACACG }\end{array}$ & 1192 \\
\hline $5-6$ & $\begin{array}{l}\text { F: GGTTGCAGGAGGTGCTTACG } \\
\text { R: GTTTCACCGTTAGCCAGGAT }\end{array}$ & 991 \\
\hline 7 & $\begin{array}{l}\text { F: AGGCTGAGGAAGGAGAATGG } \\
\text { R: GGGTAGTAGTATGGAAGAAATCGG }\end{array}$ & 406 \\
\hline $8-9$ & $\begin{array}{l}\text { F: AGGGTGGTTGGGAGTAGATG } \\
\text { R: GCAGGCTAGGCTAAGCTATGAT }\end{array}$ & 791 \\
\hline 10 & $\begin{array}{l}\text { F: GAGGCTGAGGCACAAGAATC } \\
\text { R: CCCTGGGTTTGGATGTTCTG }\end{array}$ & 601 \\
\hline 11 & $\begin{array}{l}\text { F: GCAACAAGAGTGAAACTCCGT } \\
\text { R: TTACATCTCCCAAACATCCCT }\end{array}$ & 594 \\
\hline
\end{tabular}

F, forward; R, reverse.

and $1 \mathrm{mM}$ PMSF (Sigma). Cytoplasmic extract was obtained using a Cytoplasmic Protein Extraction kit (Beyotime Institute Biotechnology). The protein concentration was determined using a BCA Protein Assay kit (Beyotime Institute Biotechnology). Immunoblots of $50 \mu \mathrm{g}$ total protein were probed with the following antibodies: cytochrome $c$, IкB, actin (Santa Cruz Biotechnology, Santa Cruz, CA, USA), Bcl-2, Bax (Zhongshan Golden Bridge Biotechnology, Wuhan, China), p21 (Boster Bio-Engineering Ltd., Wuhan, China), NF-кB-p65 (Phospho-Ser536) (SAB Signalway Antibody, Pearland, TX, USA). Protein bands were visualized using chemiluminescent reagents.

Statistical analysis. Data are presented as the means \pm SD. The differences between the groups were examined with one-way analysis of variance (ANOVA) using the SPSS 13 software (SPSS Inc., Chicago, IL, USA). $\mathrm{P}<0.05$ was considered to indicate a statistically significant difference.

\section{Results}

$5 F$ inhibits the proliferation of CNE-2Z NPC cells. In vitro, $5 \mathrm{~F}$ has been shown to inhibit cell viability of various human cancer cells (3-7). To test if 5F prevents the proliferation and growth of NPC cells, we treated CNE-2Z NPC cells with different concentrations of $5 \mathrm{~F}$ for 24,48 or $72 \mathrm{~h}$ and examined the cell proliferation using a standard MTT method. $5 \mathrm{~F}$ treatment led to a time- and dose-dependent decrease of the cell viability of CNE-2Z cells (Fig. 1B). Moreover, 5F-treated cells exhibited a rounded and granulated morphology, and were detached from culture wall after a 24-h exposure (Fig. 1C). Thus, $5 \mathrm{~F}$ also inhibits the proliferation and growth of $\mathrm{CNE}-2 \mathrm{Z}$ NPC cells.

$5 F$ induces apoptosis of $C N E-2 Z$ cells. To test whether $5 \mathrm{~F}$ inhibits the cell growth of CNE-2Z cells by inducing apoptosis, 
A

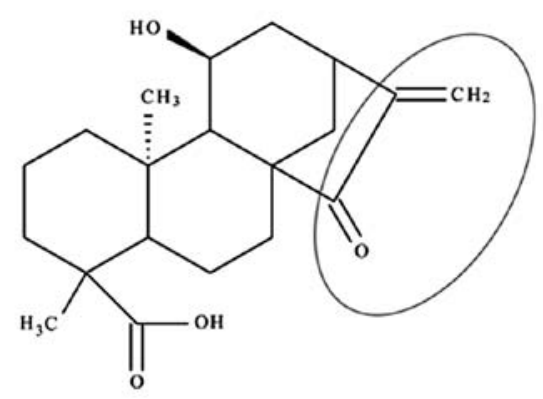

B

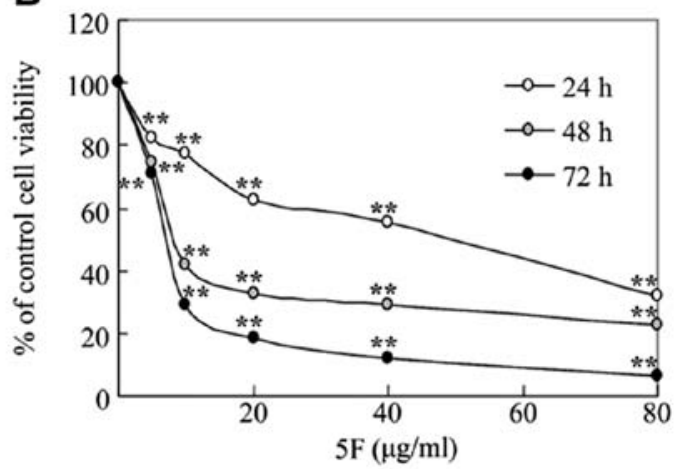

C
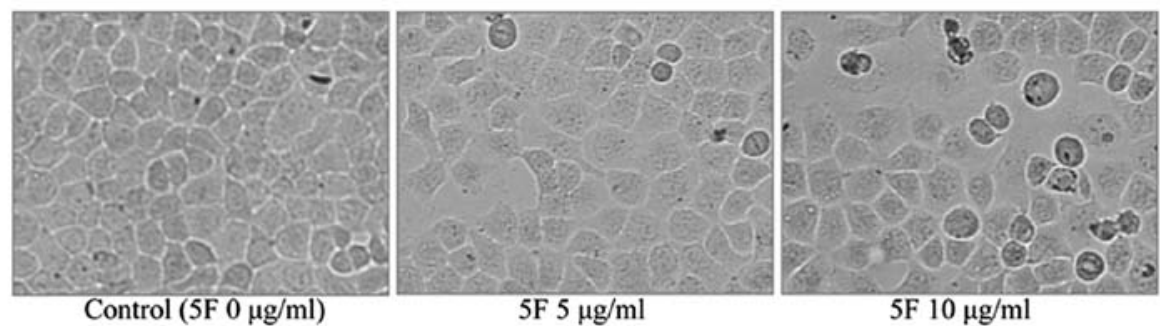

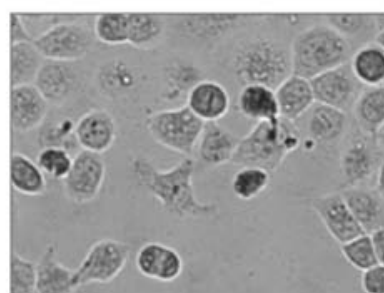

$5 \mathrm{~F} 20 \mu \mathrm{g} / \mathrm{ml}$

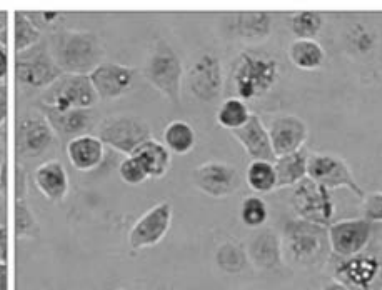

$5 \mathrm{~F} 40 \mu \mathrm{g} / \mathrm{ml}$

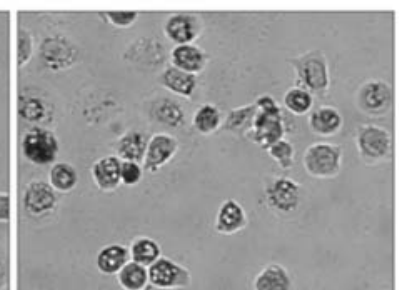

$5 \mathrm{~F} 80 \mu \mathrm{g} / \mathrm{ml}$

Figure 1. 5F inhibits the growth of CNE-2Z nasopharyngeal carcinoma cells. (A) Chemical structure of 5F. The circle indicates the conjugated double bonds structure. (B) Cell viability was examined following treatment with different concentrations of $5 \mathrm{~F}$ as indicated for 24,48 or $72 \mathrm{~h}$ using MTT assay. Drug effect was expressed as percentage relative to the controls $\left({ }^{*} \mathrm{P}<0.05,{ }^{* *} \mathrm{P}<0.01\right)$. (C) Morphology of the cells was examined $24 \mathrm{~h}$ after $5 \mathrm{~F}$ exposure under an inverted phase contrast microscope (magnification, x100).

we stained 5F-treated cells with the fluorescent dye DAPI and observed nucleus changes under the fluorescence microscope. Compared with untreated cells, 5F-treated cells demonstrated bright nuclear condensation, nuclear pyknosis and apoptotic bodies, indicating that $5 \mathrm{~F}$ induces apoptosis in CNE-2Z cells (Fig. 2A). To extend our observation, we further stained 5F-treated cells with Annexin V-FITC, an early indicator of apoptosis. As shown in Fig. 2B and C, 5F treatment of CNE-2Z cells resulted in a 5.1, 13.4, 18.9, 55 and $27.4 \%$ increase of Annexin V-positive cells at 5, 10, 20, 40 and $80 \mu \mathrm{g} / \mathrm{ml} \mathrm{5F}$, respectively. These results clearly show that $5 \mathrm{~F}$ induces significant apoptosis in CNE-2Z cells.

$5 F$ induces $G 2$ cell cycle arrest in CNE-2Z cells independently of p53-p21 axis. It has been well documented that $5 \mathrm{~F}$ induces $\mathrm{G} 2$ phase of cell cycle arrest in several cell lines. To determine whether the growth-inhibitory effect of 5F in CNE-2Z cells is associated with the induction of cell cycle arrest, we analyzed the distribution of cells in the different phases of the cell cycle using flow cytometry. Following treatment with 5, 10, 20, 40 and $80 \mu \mathrm{g} / \mathrm{ml} 5 \mathrm{~F}$ for $24 \mathrm{~h}$, the percentage of cells in the $\mathrm{G} 2 / \mathrm{M}$ phase was $11.04,12.59,15.48,34.5$ and $32.88 \%$, respectively (Fig. 3A and B), indicating that $5 \mathrm{~F}$ induces cell cycle arrest in the $\mathrm{G} 2$ phase in CNE-2Z cells.
To investigate the mechanism by which $5 \mathrm{~F}$ causes the G2-phase cell cycle arrest, we examined the effects of $5 \mathrm{~F}$ on the expression of p21, which regulates the G2-phase checkpoint (10-12). Notably, 5F significantly reduced p21 protein levels at 40 and $80 \mu \mathrm{g} / \mathrm{ml}$ (Fig. 3C and D). p21 is the critical downstream transcriptional target of $\mathrm{p} 53$, the reduction but not the increase of $\mathrm{p} 21$ by $5 \mathrm{~F}$ suggests that there may be a $\mathrm{p} 53$ mutation in CNE-2Z cells. Therefore, we sequenced the gene of p53 of CNE-2Z cells and found two types of changes. The first was a G-to-C change, at position 56 in exon 8 (Fig. 3E), and the other was a deletion of GGGCTGGGGACCTGGA in the position 16-31 in intron 3 (Fig. 3F). Thereafter, the failure to induce $\mathrm{p} 21$ by $5 \mathrm{~F}$ is likely due to the loss-of-function of p53.

$5 F$ reduces intracellular ROS levels. ROS induces endogenous DNA damages and plays an important role in apoptosis in a variety of cells. To test the possibility that $5 \mathrm{~F}$ induces cell apoptosis and G2 phase arrest by inducing ROS generation in CNE-2Z cells, we measured intracellular ROS levels. As shown in Fig. 4A and B, 5F significantly decreased ROS generation in CNE-2Z cells for $3 \mathrm{~h}$. Thus, $5 \mathrm{~F}$ reduces intracellular ROS levels and the induction of the G2 phase might not be due to the ROS-induced DNA damages. 

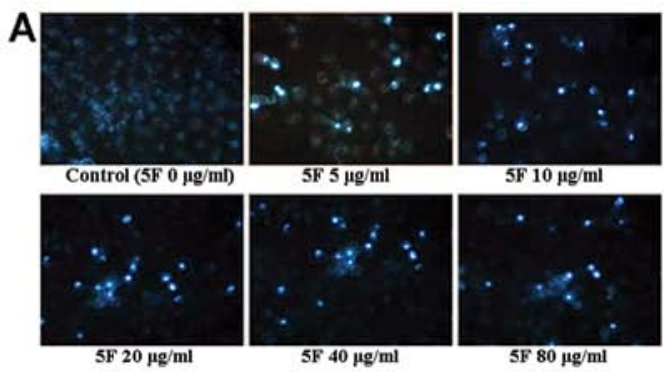

C

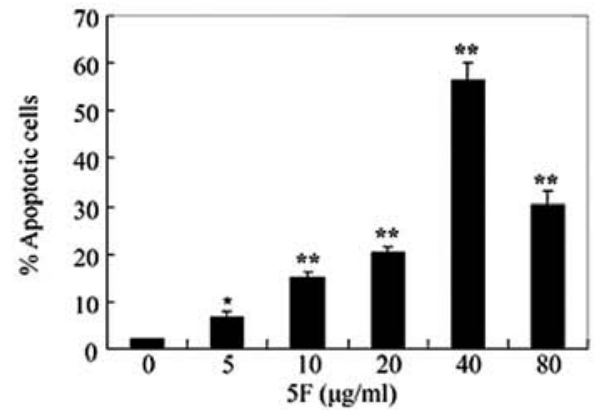

B
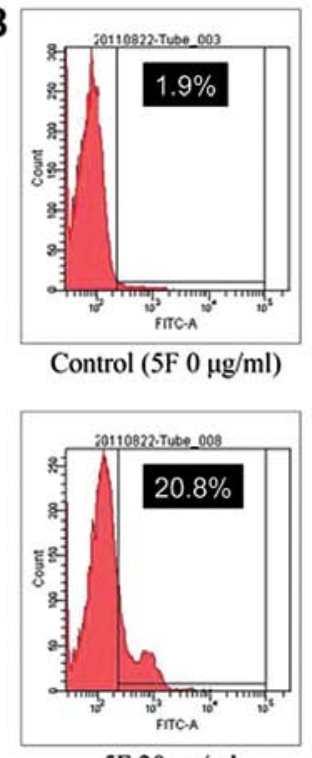

$5 \mathrm{~F} 20 \mu \mathrm{g} / \mathrm{ml}$

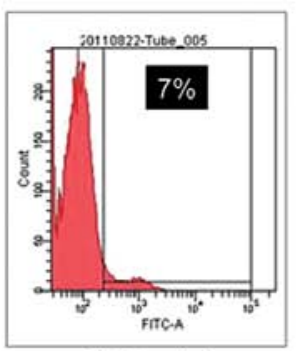

5F $5 \mu \mathrm{g} / \mathrm{ml}$

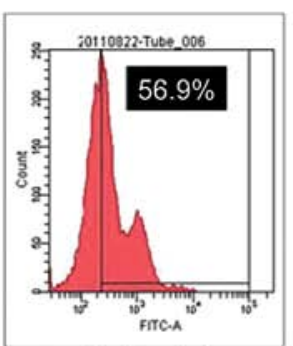

$5 \mathrm{~F} 40 \mu \mathrm{g} / \mathrm{ml}$

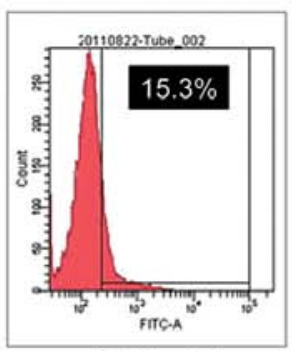

$5 \mathrm{~F} 10 \mu \mathrm{g} / \mathrm{ml}$

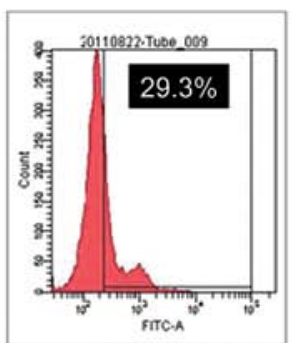

$5 \mathrm{~F} 80 \mu \mathrm{g} / \mathrm{ml}$

Figure 2. $5 \mathrm{~F}$ induces apoptosis of CNE-2Z cells. (A) Cells were fixed with $4 \%$ paraformaldehyde for 20 min, washed with PBS, and then incubated with DAPI $(2 \mu \mathrm{g} / \mathrm{ml})$ at room temperature for $10 \mathrm{~min}$ (magnification, $\mathrm{x} 100)$. (B) Following treatment with $5 \mathrm{~F}$ for $24 \mathrm{~h}$, cells were harvested, washed with PBS, resuspended in binding buffer and then incubated with Annexin V-FITC for $15 \mathrm{~min}$ in the dark at $4^{\circ} \mathrm{C}$ and subjected to flow cytometry analysis. (C) Quantification of (B). ${ }^{*} \mathrm{P}<0.05,{ }^{* * *} \mathrm{P}<0.01$.

A
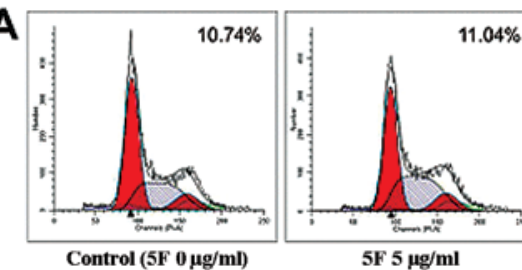

$11.04 \%$
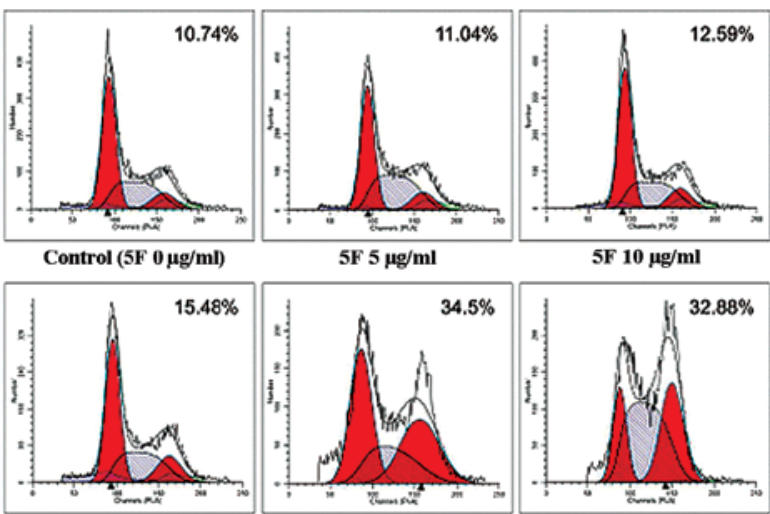

5F $20 \mu \mathrm{g} / \mathrm{ml}$

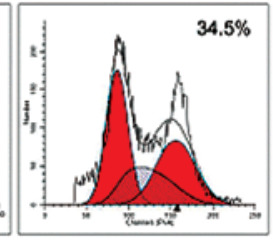

$5 \mathrm{~F} 40 \mu \mathrm{g} / \mathrm{ml}$

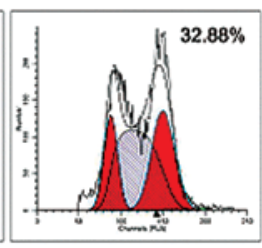

$5 \mathrm{~F} 80 \mu \mathrm{g} / \mathrm{ml}$
B

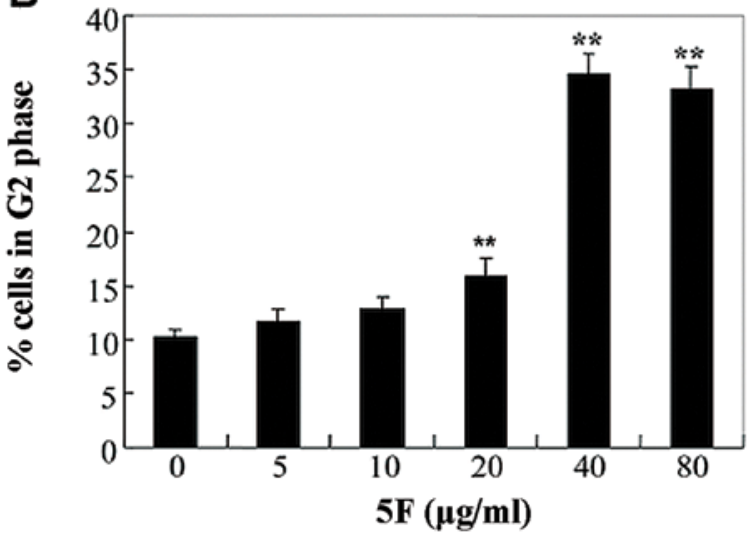

C

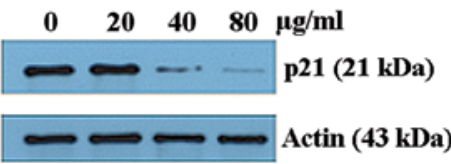

D

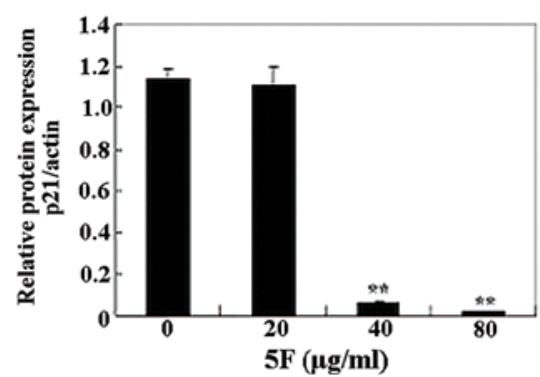

E

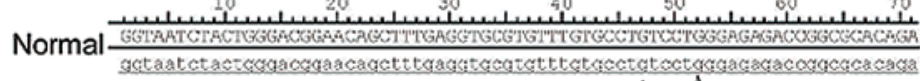

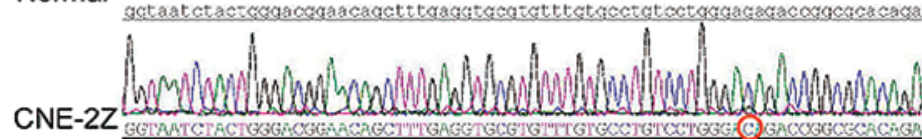

$\mathbf{F}$

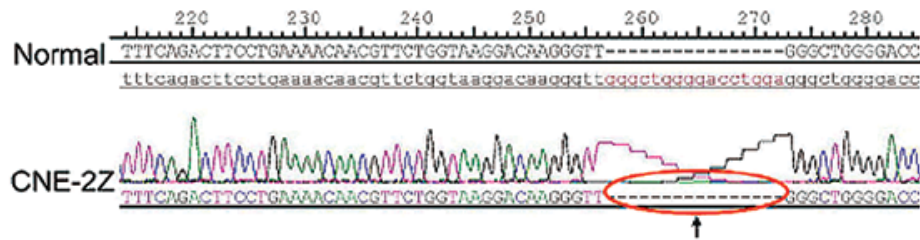

Figure 3. 5F induces $\mathrm{G} 2$ cell cycle arrest in CNE-2Z cells independently of p53-p21 axis. (A) Following treatment with 5F for $24 \mathrm{~h}$, cells were fixed overnight with $70 \%$ ethanol at $-20^{\circ} \mathrm{C}$ and stained with PI solution. Cell cycle distribution analysis was performed using a flow cytometer. (B) Representative cell cycle histogram of (A) demonstrating the percentage of the cells in the G2 phase. Compared with blank control $\left.{ }^{* *} \mathrm{P}<0.01\right)$. (C) Effect of $5 \mathrm{~F}$ on p21 expression, as measured by western blot analysis. Compared with blank control $\left({ }^{* *} \mathrm{P}<0.01\right)$. (D) Quantification of (C). ${ }^{* *} \mathrm{P}<0.01$. (E) Sequencing analysis shows (arrows) a G-to-C change, at position 56 of exon 8 of the TP53 gene. (F) Sequencing analysis shows (arrows) a deletion of gggctggggacctgga in the position 16-31 of intron 3 of the TP53 gene. 
A
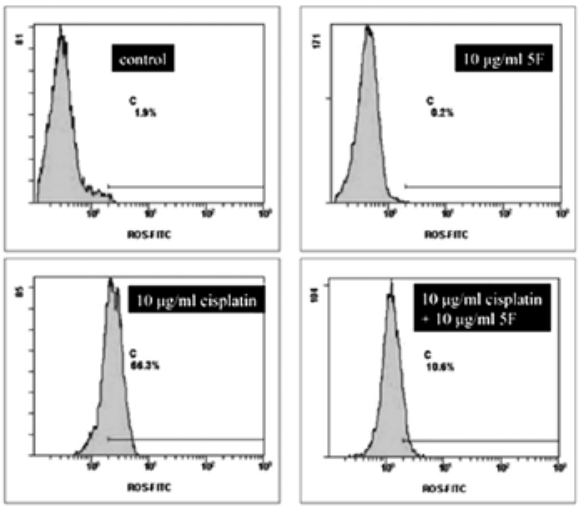

B

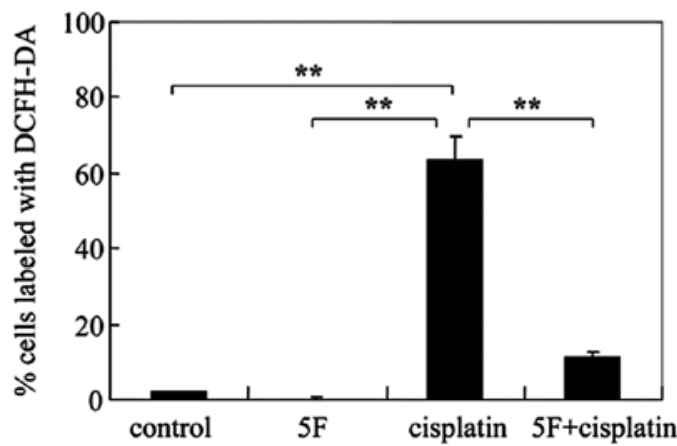

C

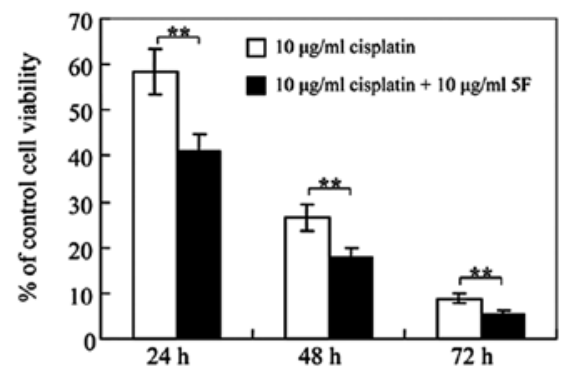

D

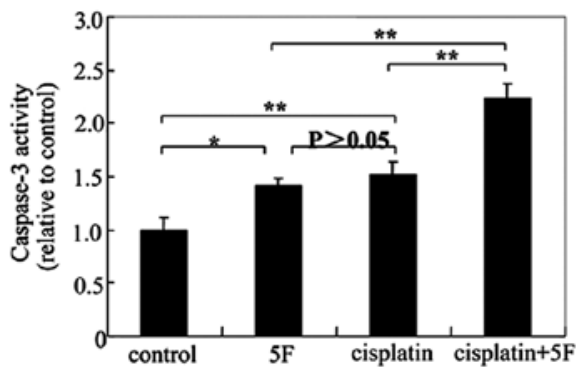

Figure 4. 5F reduces intracellular ROS levels and sensitizes CNE- $2 \mathrm{Z}$ cells to cisplatin. (A) Cells were exposed to $5 \mathrm{~F}$, cisplatin, or a combination of $5 \mathrm{~F}$ and cisplatin for $3 \mathrm{~h}$, and incubated in the dark with $10 \mu \mathrm{M} \mathrm{DCFH-DA}$ for $20 \mathrm{~min}$ at $37^{\circ} \mathrm{C}$. ROS generation was detected using a FACScan flow cytometer. (B) Quantification of (A). ${ }^{* *} \mathrm{P}<0.01$. (C) Cells were treated with 5F, cisplatin, or a combination of 5F and cisplatin for 24, 48 and 72 h. MTT assays were used to check the viability. ${ }^{* *} \mathrm{P}<0.01$. (D) Cells were treated as in (A). Caspase-3 activity was measured using Caspase-3 Colorimetric assay. Caspase-3 activity was expressed as: $\mathrm{OD}_{\text {test compound }} / \mathrm{OD}_{\text {control. }}{ }^{*} \mathrm{P}<0.05,{ }^{* *} \mathrm{P}<0.01$.

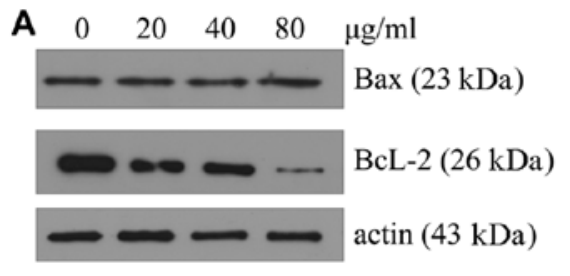

B

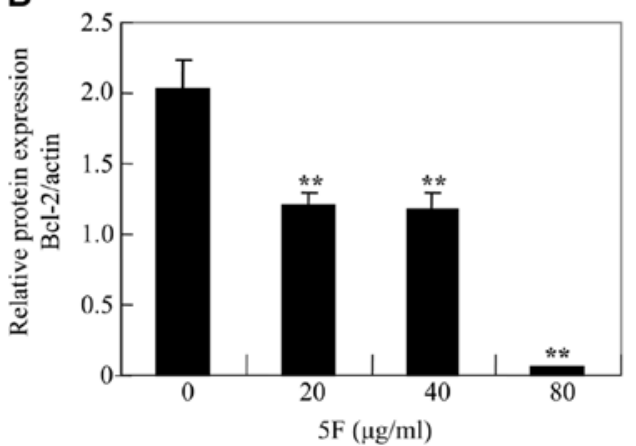

C

$$
\begin{array}{lllll}
0 & 20 & 40 & 80 & \mu \mathrm{g} / \mathrm{ml} \\
& - & \text { Cyto c in cytosol }(15 \mathrm{kDa}) \\
& - & - & -
\end{array}
$$

D

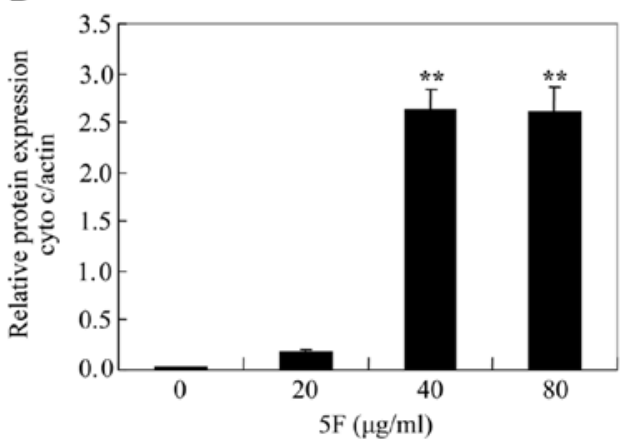

Figure 5. 5F downregulates the ratio of Bcl-2/Bax. (A) Cells were treated with different concentrations of $5 \mathrm{~F}$ as indicated for $24 \mathrm{~h}$. Bax and Bcl-2 proteins were measured by western blot analysis. (B) Quantification of Bcl-2 relative to actin of (A). ${ }^{* *} \mathrm{P}<0.01$. (C) Cells were treated as in (A). Effects of $5 \mathrm{~F}$ on the release of cytochrome $c$ from mitochondria into the cytosol were measured by western blot analysis. (D) Quantification of (C). ${ }^{* *} \mathrm{P}<0.01$.

$5 F$ sensitizes $C N E-2 Z$ cells to cisplatin independently of its reduction of ROS. It has been reported that cisplatin cytotoxicity is mediated by increased generation of ROS. Several reports have demonstrated that cisplatin-induced cytotoxicity could be ameliorated by using antioxidants or oxygen radical scavengers (13-15). The reduction of ROS by $5 \mathrm{~F}$ predicts that 
A

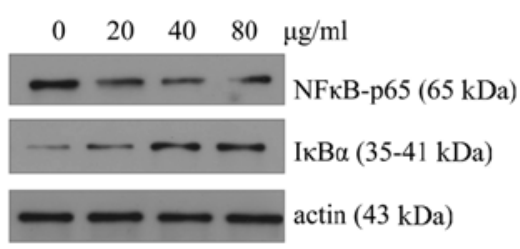

B

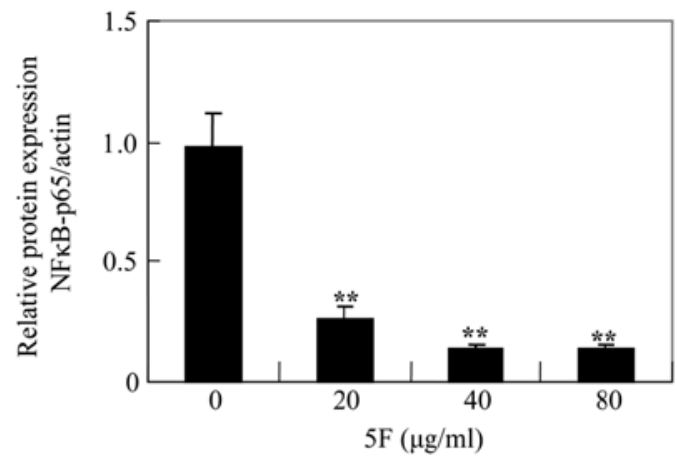

C

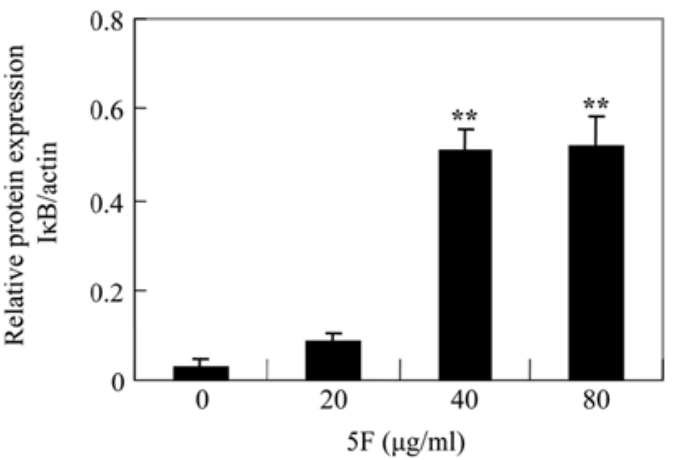

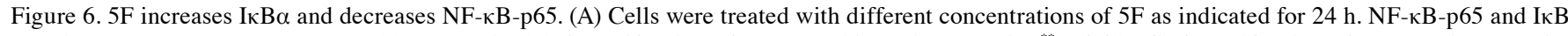

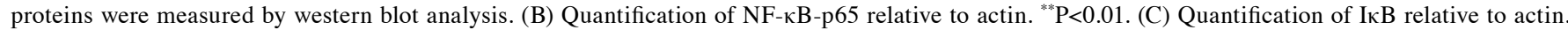
${ }^{* *} \mathrm{P}<0.01$.

5F may attenuate cisplatin cytotoxicity. We thus determined whether 5F antagonizes cisplatin-stimulated intracellular ROS generation. We found that cisplatin increased ROS production (Fig. 4A and B) and 5F reduced the ROS production in cisplatin-treated CNE-2Z cells, whereas $5 \mathrm{~F}$ significantly sensitized CNE-2Z cells to cisplatin-induced cytotoxicity after 24,48 and $72 \mathrm{~h}$ of treatment (Fig. 4C). Moreover, a synergistic interaction in increasing caspase- 3 activity was also observed when $5 \mathrm{~F}$ $(10 \mu \mathrm{g} / \mathrm{ml})$ was added to $10 \mu \mathrm{g} / \mathrm{ml}$ of cisplatin in CNE-2Z NPC cells (Fig. 4D). Thus, 5F sensitizes CNE-2Z cells to cisplatin via the apoptosis pathway.

$5 F$ downregulates $B c l-2$ and upregulates $I \kappa B \alpha$. To elucidate the mechanism by which $5 \mathrm{~F}$ induces apoptosis in CNE-2Z cells, we measured the protein levels of Bcl-2 and Bax. Treatment of CNE-2Z cells with $5 \mathrm{~F}$ resulted in a dose-dependent decrease of anti-apoptotic Bcl-2 protein. By contrast, $5 \mathrm{~F}$ did not significantly influence the expression of the pro-apoptotic Bax protein (Fig. 5A and B). Accordingly, 5F induced a dose-dependent release of cytochrome $c$ from mitochondrion (Fig. 5C and D). These data indicated that 5F induces the activation of mitochondrial-mediated internal apoptosis pathway by downregulating Bcl-2.

$\mathrm{Bcl}-2$ is regulated by nuclear factor $\kappa \mathrm{B}(\mathrm{NF}-\kappa \mathrm{B})$. To test if $5 \mathrm{~F}$ induces apoptosis by downregulating $\mathrm{Bcl}-2$ through $\mathrm{NF}-\kappa \mathrm{B}$, we examined p65, a subunit of NF- $\kappa \mathrm{B}$, and $\mathrm{I} \kappa \mathrm{B} \alpha$, an inhibitor of NF-kB (16). We found that the level of p65 was reduced by $5 \mathrm{~F}$ whereas the level of I $\mathrm{KB} \alpha$ was upregulated by $5 \mathrm{~F}$ (Fig. 6). These results suggest that $5 \mathrm{~F}$ might induce apoptosis of CNE-2Z cells by downregulating Bcl-2 by decreasing $\mathrm{NF \kappa B}$ signaling.

\section{Discussion}

In the present study, we demonstrated that $5 \mathrm{~F}$ significantly inhibited the proliferation of CNE-2Z cells in a dose- and time-dependent manner, and this inhibitory effect was p53 independent. Moreover, $5 \mathrm{~F}$ induced mitochondrial-mediated apoptosis in CNE-2Z cells, accompanied by a decrease of Bcl-2 and NF- $\kappa$ B. Finally, we found that $5 \mathrm{~F}$ sensitized CNE-2Z cells to cisplatin independently of its reduction of ROS. Our data suggest that $5 \mathrm{~F}$ may be a potential anti-NPC agent.

Deregulation of cell cycle progression and evasion of apoptosis are hallmarks of cancer cells (17). Accordingly, inhibition of cell cycle progression may be particularly useful in the treatment of cancer. $5 \mathrm{~F}$ has been demonstrated to arrest cells at the G2 phase in FRO cells (an anaplastic thyroid carcinoma cell line) and A549 cells (a non-small cell lung cancer cell line) $(5,3)$. Consistent with these reports, the present study showed that $5 \mathrm{~F}$ could induce $\mathrm{G} 2$-phase arrest in CNE-2Z cells. The G2 phase of the cell cycle is controlled by cyclin-dependent kinase 1 (CDK1) and can be inhibited by upregulation of the cyclin-dependent kinase (CDK) inhibitor p21 (18). Several studies have shown that anticancer drugs can increase the number of cells in $\mathrm{G} 2 / \mathrm{M}$ cell cycle phases, accompanied by upregulation of p21 (19-23). Therefore, we measured the expression of $\mathrm{p} 21$ in CNE-2Z cells to further investigate the reason for the G2/M-phase arrest mediated by $5 \mathrm{~F}$. Markedly, our results showed that $5 \mathrm{~F}$ reduced the expression of $\mathrm{p} 21$ in CNE-2Z cells. In fact, the functions of p21 are very complex. Despite the critical role of p21 in arresting cell cycle progression and promoting differentiation and senescence, it was shown that p21 could also promote cellular proliferation 
and tumorigenesis under certain conditions. Consequently, depending on the cellular context and circumstances, p21 is often deregulated in human cancer, suggesting that it can act either as a tumor suppressor or as an oncogene (24). The tumor suppressor p53 is a nuclear transcription factor that induces the expression of its numerous downstream targets including $\mathrm{p} 21$, leading to cell cycle arrest, senescence and apoptosis (25). In the present study, we found p53 is a mutant in CNE-2Z cells. The reduction of $\mathrm{p} 21$ by $5 \mathrm{~F}$ in CNE-2Z cells may be partly due to the p53 mutation.

Previous reports have shown that several antitumor agents (such as cisplatin) arrest cell cycle at the G2/M phase, accompanied by apoptosis (26). Induction of tumor cell death by apoptosis is a major mechanism employed by antitumor agents. In the present study, we demonstrated apoptosisinducing effects of $5 \mathrm{~F}$ in CNE-2Z cells using DAPI staining and Annexin V-FITC staining assay. The mitochondrialmediated apoptotic pathway contributes to apoptosis of cancer cells induced by several antitumor agents (27-29). Elevated ratio of $\mathrm{Bax} / \mathrm{Bcl} 2$ is an important marker of apoptosis in several cancer cells $(23,30-33)$. Based on the quantification of western blot signals by densitometry, an approximately 23 -fold increase of $\mathrm{Bax} / \mathrm{Bcl} 2$ was observed following treatment with $80 \mu \mathrm{g} / \mathrm{ml}$ of $5 \mathrm{~F}$ for $24 \mathrm{~h}$ (Fig. 5A and B). In addition, the release of cytochrome $c$ from mitochondria into the cytosol was also observed. These results suggest that $5 \mathrm{~F}$-induced apoptosis in CNE-2Z cells is mediated, at least in part, by the mitochondrial pathway. On the other hand, caspase-3 plays a pivotal role in the terminal execution phase of apoptosis (34). An increasing caspase- 3 activity was observed when $10 \mu \mathrm{g} / \mathrm{ml}$ of $5 \mathrm{~F}$ was added to $10 \mu \mathrm{g} / \mathrm{ml}$ of cisplatin in CNE-2Z cells, which suggests that the sensitization of CNE- $2 \mathrm{Z}$ cells by $5 \mathrm{~F}$ to cisplatin is associated with enhanced apoptosis.

The transcription factor NF- $\mathrm{KB}$ is an important mediator of cell cycle progression and cell survival associated with carcinogenesis (35). Upregulation of NF- $\kappa \mathrm{B}$ is positively associated with poor outcome of several types of cancer, including NPC $(36,37)$. In resting cells, NF- $\mathrm{kB}$ exists in the cytoplasm and is inhibited by complexing with IкB. Phosphorylation of I $\kappa$ by I $\mathrm{I} B$ kinase (IKK) causes ubiquitination and degradation of I $\kappa B$. Subsequently, NF- $\kappa B$ is released and translocates to the nucleus, where NF- $\mathrm{KB}$ regulates the transcription of a number of genes which are involved in tumorigenesis and cell growth $(38,35)$. These findings indicate that NF- $\kappa \mathrm{B}$ is a potential therapeutic target in cancer. In the present study, we investigated the effects of $5 \mathrm{~F}$ on the pattern of NF- $\mathrm{KB}$ activation. Our results showed that treatment of CNE-2Z cells with $5 \mathrm{~F}$ significantly inhibited the expression of $\mathrm{p}-\mathrm{NF}-\mathrm{\kappa B} / \mathrm{p} 65$ protein and degradation of I $\mathrm{I} B \alpha$ protein. This study suggested that the effects of $5 \mathrm{~F}$ on NF- $\mathrm{kB} / \mathrm{p} 65$ might be through inhibition of the phosphorylation and subsequent proteolysis of IкB $\alpha$.

Several antitumor agents such as cisplatin, adriamycin (ADR), bleomycin and tumor necrosis factor (TNF) have been reported to exert cytotoxic effects through ROS induction (39-42), therefore, we determined the role of ROS formation in 5F-induced cell death in CNE-2Z cells. Notably, 5F induced apoptosis and, at the same time, reduced the ROS generation in CNE-2Z cells. ROS scavenging of $5 \mathrm{~F}$ might be related to conjugated double bonds. Cisplatin is one of the most effective chemotherapeutic agents, but has prominent side-effects such as nephrotoxicity. These side-effects are believed to be related to its ability to induce ROS production $(43,44)$. Animal studies have indicated that antioxidants or oxygen radical scavengers could either ameliorate or protect against cisplatin toxicity $(44,45)$. Results from the current study demonstrated that $5 \mathrm{~F}$ possesses antioxidant properties in addition to anticancer properties. Therefore, $5 \mathrm{~F}$ combined with cisplatin might improve cisplatin anticancer effects by reducing the cisplatin-induced ROS.

In conclusion, $5 \mathrm{~F}$ inhibited $\mathrm{CNE}-2 \mathrm{Z}$ cell proliferation through cell cycle arrest at the G2/M phase and apoptosis induction related to the mitochondrial-mediated apoptotic pathway and NF- $\mathrm{KB}$ inhibition. Our results also indicate that $5 \mathrm{~F}$ sensitizes CNE-2Z cells to cisplatin-induced cytotoxicity and reduces ROS production induced by cisplatin. Our previous studies in mice showed that $5 \mathrm{~F}$ could be effective against liver and lung cancer with minimal side-effects $(46,47)$. These results suggest $5 \mathrm{~F}$ is a promising anti-NPC agent.

\section{Acknowledgements}

This study was supported by the National Natural Science Foundation of China (no. 3987099), the Science and Technology Innovation Fund of Guangdong Medical College (STIF201104) and the Research Committee, Guangdong Medical College (no. XB0601).

\section{References}

1. Chen WQ, Zeng HM, Zheng RS, Zhang SW and He J: Cancer incidence and mortality in China, 2007. Chin J Cancer Res 24: $1-8,2012$.

2. Chang JT, Ko JY and Hong RL: Recent advances in the treatment of nasopharyngeal carcinoma. J Formos Med Assoc 103: 496-510, 2004.

3. Li L, Chen GG, Lu YN, Liu Y, Wu KF, Gong XL, Gou ZP, Li MY and Liang NC: Ent-11 $\alpha$-hydroxy-15-oxo-kaur-16-en-19oic-acid inhibits the growth of human lung cancer A549 cells by arresting cell cycle and triggering apoptosis. Chin J Cancer Res 24: 109-115, 2012.

4. Vlantis AC, Lo CS, Chen GG, Ci Liang N, Lui VW, Wu K, Deng YF, Gong X, Lu Y, Tong MC and van Hasselt CA: Induction of laryngeal cancer cell death by Ent-11-hydroxy-15-oxo-kaur16-en-19-oic acid. Head Neck 32: 1506-1518, 2010.

5. Liu ZM, Chen GG, Vlantis AC, Liang NC, Deng YF and van Hasselt CA: Cell death induced by ent-11alpha-hydroxy15-oxo-kaur-16-en-19-oic-acid in anaplastic thyroid carcinoma cells is via a mitochondrial-mediated pathway. Apoptosis 10: 1345-1356, 2005.

6. Liu Z, Ng EK, Liang NC, Deng YF, Leung BC and Chen GG: Cell death induced by Pteris semipinnata $\mathrm{L}$. is associated with p53 and oxidant stress in gastric cancer cells. FEBS Lett 579: 1477-1487, 2005

7. Chen GG, Liang NC, Lee JF, Chan UP, Wang SH, Leung BC and Leung KL: Over-expression of Bcl-2 against Pteris semipinnata L-induced apoptosis of human colon cancer cells via a NF-kappa B-related pathway. Apoptosis 9: 619-627, 2004

8. Gu SY, Zhao WP, Zeng Y, Tang WP, Zhao ML, Deng HH and Li K: New human nasopharyngeal epithelial cell line established from a patient with poorly differentiated nasopharyngeal carcinoma. Chin J Cancer 2: 70-72, 1983.

9. Deng YF and Liang NC: Study on extraction and separation of diterpenoids from Pteris semipinnata. Chin Pharm J 39: 742-744, 2004.

10. Sherr CJ: Cancer cell cycles. Science 274: 1672-1677, 1996.

11. Nigg EA: Cyclin-dependent protein kinases: key regulators of the eukaryotic cell cycle. Bioessays 17: 471-480, 1995.

12. Gautier J, Solomon MJ, Booher RN, Bazan JF and Kirschner MW: cdc25 is a specific tyrosine phosphatase that directly activates p34cdc2. Cell 67: 197-211, 1991. 
13. Jiang M, Wei Q, Pabla N, Dong G, Wang CY, Yang T, Smith SB and Dong Z: Effects of hydroxyl radical scavenging on cisplatininduced $\mathrm{p} 53$ activation, tubular cell apoptosis and nephrotoxicity. Biochem Pharmacol 73: 1499-1510, 2007.

14. Kim YH, Kim YW, Oh YJ, Back NI, Chung SA, Chung HG Jeong TS, Choi MS and Lee KT: Protective effect of the ethanol extract of the roots of Brassica rapa on cisplatin-induced nephrotoxicity in LLC-PK 1 cells and rats. Biol Pharm Bull 29: 2436-2441, 2006.

15. Satoh M, Kashihara N, Fujimoto S, Horike H, Tokura T, Namikoshi T, Sasaki T and Makino H: A novel free radical scavenger, edarabone, protects against cisplatin-induced acute renal damage in vitro and in vivo. J Pharmacol Exp Ther 305: $1183-1190,2003$

16. Van Waes C: Nuclear factor-kappaB in development, prevention, and therapy of cancer. Clin Cancer Res 13: 1076-1082, 2007.

17. Senderowicz AM: Targeting cell cycle and apoptosis for the treatment of human malignancies. Curr Opin Cell Biol 16: 670-678, 2004

18. Skladanowski A, Côme MG, Sabisz M, Escargueil AE and Larsen AK: Down-regulation of DNA topoisomerase IIalpha leads to prolonged cell cycle transit in G2 and early M phases and increased survival to microtubule-interacting agents. Mol Pharmacol 68: 625-634, 2005.

19. Cho JH, Lee JG, Yang YI, Kim JH, Ahn JH, Baek NI, Lee KT and Choi JH: Eupatilin, a dietary flavonoid, induces G2/M cell cycle arrest in human endometrial cancer cells. Food Chem Toxicol 49: 1737-1744, 2011.

20. Castro J, Ribó M, Navarro S, Nogués MV, Vilanova $M$ and Benito A: A human ribonuclease induces apoptosis associated with $\mathrm{p} 21^{\mathrm{WAF} / / \mathrm{CIP} 1}$ induction and JNK inactivation. BMC Cancer 11: $9,2011$.

21. Kalimutho M, Minutolo A, Grelli S, Formosa A, Sancesario G, Valentini A, Federici G and Bernardini S: Satraplatin (JM-216) mediates G2/M cell cycle arrest and potentiates apoptosis via multiple death pathways in colorectal cancer cells thus overcoming platinum chemo-resistance. Cancer Chemother Pharmacol 67: 1299-1312, 2011.

22. Huang WW, Ko SW, Tsai HY, Chung JG, Chiang JH, Chen KT, Chen YC, Chen HY, Chen YF and Yang JS: Cantharidin induces $\mathrm{G} 2 / \mathrm{M}$ phase arrest and apoptosis in human colorectal cancer colo 205 cells through inhibition of CDK1 activity and caspasedependent signaling pathways. Int J Oncol 38: 1067-1073, 2011.

23. Dia VP and Mejia EG: Lunasin promotes apoptosis in human colon cancer cells by mitochondrial pathway activation and induction of nuclear clusterin expression. Cancer Lett 295: 44-53, 2010.

24. Abbas T and Dutta A: p21 in cancer: intricate networks and multiple activities. Nat Rev Cancer 9: 400-414, 2009.

25. Vousden KH and Prives C: Blinded by the light: the growing complexity of p53. Cell 137: 413-431, 2009.

26. Chu G: Cellular responses to cisplatin: The roles of DNA-binding proteins and DNA repair. J Biol Chem 269: 787-790, 1994.

27. Malugin A, Kopecková P and Kopecek J: HPMA copolymerbound doxorubicin induces apoptosis in ovarian carcinoma cells by the disruption of mitochondrial function. Mol Pharm 3: 351-361, 2006

28. Yim EK, Lee KH, Bae JS, Namkoong SE, Um SJ and Park JS: Proteomic analysis of antiproliferative effects by treatment of 5-fluorouracil in cervical cancer cells. DNA Cell Biol 23 769-776, 2004

29. Boulikas T and Vougiouka M: Cisplatin and platinum drugs at the molecular level (Review). Oncol Rep 10: 1663-1682, 2003.

30. Lin JP, Yang JS, Lee JH, Hsieh WT and Chung JG: Berberine induces cell cycle arrest and apoptosis in human gastric carcinoma SNU-5 cell line. World J Gastroenterol 12: 21-28, 2006.
31. Hwang JM, Kuo HC, Tseng TH, Liu JY and Chu CY: Berberine induces apoptosis through a mitochondria/caspases pathway in human hepatoma cells. Arch Toxicol 80: 62-73, 2006.

32. Mantena SK, Sharma SD and Katiyar SK: Berberine, a natural product, induces G1-phase cell cycle arrest and caspase-3-dependent apoptosis in human prostate carcinoma cells. Mol Cancer Ther 5: 296-308, 2006.

33. Kuo CL, Chou CC and Yung BY: Berberine complexes with DNA in the berberine-induced apoptosis in human leukemic HL-60 cells. Cancer Lett 93: 193-200, 1995.

34. Vaux DL and Korsmeyer SJ: Cell death in development. Cell 96: 245-254, 1999

35. Aggarwal BB: Nuclear factor-kappaB: the enemy within. Cancer Cell 6: 203-208, 2004

36. Sun W, Guo MM, Han P, Lin JZ, Liang FY, Tan GM, Li HB, Zeng $M$ and Huang XM: Id-1 and the p65 subunit of NF- $\kappa B$ promote migration of nasopharyngeal carcinoma cells and are correlated with poor prognosis. Carcinogenesis 33: 810-817, 2012.

37. Zhang Y, Lang JY, Liu L, Wang J, Feng G, Jiang Y, Deng YL, Wang XJ, Yang YH, Dai TZ, Xie G, Pu J and Du XB: Association of nuclear factor $\mathrm{\kappa B}$ expression with a poor outcome in nasopharyngeal carcinoma. Med Oncol 28: 1338-1342, 2011.

38. Gupta S, Hastak K, Afaq F, Ahmad N and Mukhtar H: Essential role of caspases in epigallocatechin-3-gallate-mediated inhibition of nuclear factor kappa B and induction of apoptosis. Oncogene 23: 2507-2522, 2004 .

39. Miyajima A, Nakashima J, Yoshioka K, Tachibana M, Tazaki H and Murai M: Role of reactive oxygen species in cis-dichlorodiammineplatinum-induced cytotoxicity on bladder cancer cells. Br J Cancer 76: 206-210, 1997.

40. Meijer C, Mulder NH, Timmer-Bosscha H, Zijlstra JG and de Vries EG: Role of free radicals in an adriamycin-resistant human small cell lung cancer cell line. Cancer Res 47: 4613-4617, 1987.

41. Sausville EA, Stein RW, Peisach J and Horwitz SB: Properties and products of the degradation of DNA by bleomycin and iron (II). Biochemistry 17: 2746-2754, 1978

42. Yamauchi N, Kuriyama H, Watanabe N, Neda H, Maeda M and Niitsu Y: Intracellular hydroxyl radical production induced by recombinant human tumor necrosis factor and its implication in the killing of tumor cells in vitro. Cancer Res 49: 1671-1675, 1989.

43. Chirino YI and Pedraza-Chaverri J: Role of oxidative and nitrosative stress in cisplatin-induced nephrotoxicity. Exp Toxicol Pathol 61: 223-242, 2009.

44. Rybak LP, Whitworth CA, Mukherjea D and Ramkumar V: Mechanisms of cisplatin-induced ototoxicity and prevention. Hear Res 226: 157-167, 2007.

45. van den Berg JH, Beijnen JH, Balm AJ and Schellens JH: Future opportunities in preventing cisplatin induced ototoxicity. Cancer Treat Rev 32: 390-397, 2006.

46. Chen GG, Leung J, Liang NC, Li L, Wu K, Chan UP, Leung BC, Li M, Du J, Deng YF, Gong X, Lv Y, Chak EC and Lai PB: Ent-11 $\alpha$-hydroxy-15-oxo-kaur-16-en-19-oic-acid inhibits hepatocellular carcinoma in vitro and in vivo via stabilizing IкB $\alpha$. Invest New Drugs 30: 2210-2218, 2012.

47. Li MY, Leung J, Kong AW, Liang NC, Wu K, Hsin MK, Deng YF, Gong X, Lv Y, Mok TS, Underwood MJ and Chen GG: Anticancer efficacy of 5F in NNK-induced lung cancer development of A/J mice and human lung cancer cells. J Mol Med 88: 1265-1276, 2010 